\title{
LATE CRETACEOUS-EARLY PALEOGENE (TURONIAN? TO EARLY DANIAN) PLANKTIC FORAMINIFERA FROM DSDP SITE 356: A BIOSTRATIGRAPHIC REAPPRAISAL
}

\author{
KARLOS GUILHERME DIEMER KOCHHANN \\ Marine Mikropaläontologie, Institut für Geowissenschaften, Christian-Albrechts-Universität, \\ Olshausenstrasse 40-60, Kiel 24118, Germany.kochhann@gpi.uni-kiel.de \\ FERNANDO MARCANTH LOPES, GUILHERME KRAHL, \\ EDUARDO AGUIAR \& GERSON FAUTH \\ ITT FOSSIL - Instituto Tecnológico de Micropaleontologia, Universidade do Vale do Rio dos Sinos, \\ Av.UNISINOS, 950, 93022-000, São Leopoldo, RS, Brazil.fernandoml@unisinos.br,gkrahl@unisinos.br, \\ eaguiar@unisinos.br,gersonf@unisinos.br
}

\begin{abstract}
Biostratigraphic results obtained with a systematic study of the planktic foraminiferal assemblages recovered from Upper Cretaceous-Lower Paleogene strata (Turonian? to early Danian in age) of Deep Sea Drilling Program (DSDP) Site 356, São Paulo Plateau, are presented and discussed herein. Fifty-nine planktic foraminiferal species were identified within the studied interval, enabling the identification of 11 planktic foraminiferal zones (Turonian? to early Danian in age): Marginotruncana schneegansi, Dicarinella concavata, Dicarinella asymetrica, Globotruncanita elevata, Contusotruncana plummerae, Radotruncana calcarata, Globotruncanella havanensis, Pseudoguembelina palpebra, Abathomphalus mayaroensis, Pseudoguembelina hariaensis and $\mathrm{P} \alpha$. An unconformity spanning at least 0.96 Ma could also be suggested within core 31 (Maastrichtian in age), due to the absence of the Racemiguembelina fructicosa Interval Zone from the studied section. High sedimentation rates were estimated within the Santonian (Dicarinella asymentrica Total-range Zone) and the uppermost Maastrichtian (Pseudoguembelina hariaensis Interval Zone) of DSDP site 356, while lower and more constant values were suggested for the Campanian-lower Maastrichtian interval (Globotruncanita elevata Partial-range Zone to Pseudoguembelina palpebra Interval Zone). The reliability in identifying the Contusotruncana plummerae Interval Zone (Campanian in age) in Cretaceous sections of the South Atlantic Ocean is confirmed herein.
\end{abstract}

Key words: planktic foraminifera, biostratigraphy, Turonian?-early Danian, São Paulo Plateau, DSDP Site 356.

RESUMO - Resultados bioestratigráficos obtidos com o estudo sistemático das assembleias de foraminíferos planctônicos recuperadas de estratos atribuídos ao intervalo Cretáceo Superior-Paleógeno inferior (de idade turoniana?-daniana inicial) do Deep Sea Drilling Program (DSDP) Site 356, Platô de São Paulo, são aqui apresentados e discutidos. No intervalo estudado, foram identificadas 59 espécies de foraminíferos planctônicos, permitindo o reconhecimento de 11 zonas (de idade turoniana?-daniana inicial): Marginotruncana schneegansi, Dicarinella concavata, Dicarinella asymetrica, Globotruncanita elevata, Contusotruncana plummerae, Radotruncana calcarata, Globotruncanella havanensis, Pseudoguembelina palpebra, Abathomphalus mayaroensis, Pseudoguembelina hariaensis e P $\alpha$. A presença de uma discordância abrangendo ao menos $0.96 \mathrm{Ma}$ foi sugerida no interior do testemunho 31 (de idade maastrichtiana), devido à ausência da Zona de Intervalo Racemiguembelina fructicosa. Altas taxas de sedimentação foram estimadas para os intervalos Santoniano (Zona de Amplitude Dicarinella asymentrica) e Maastrichtiano superior (Zona de Intervalo Pseudoguembelina hariaensis) do DSDP Site 356, enquanto valores mais baixos e mais constantes são sugeridos para o intervalo Campaniano-Maastrichtiano inferior (Zona de Amplitude Parcial Globotruncanita elevata à Zona de Intervalo Pseudoguembelina palpebra). O presente estudo confirma a viabilidade da identificação da Zona de Intervalo Contusotruncana plummerae (de idade campaniana) em seções cretáceas do Oceano Atlântico Sul.

Palavras-chave: foraminíferos planctônicos, bioestratigrafia, Turoniano?-Daniano inicial, Platô de São Paulo, DSDP Site 356. 


\section{INTRODUCTION}

During the Cretaceous period, planktic foraminifera experienced their highest rates of speciation, enabling the identification of a series of high-resolution global bioevents, from the Aptian through the Maastrichtian (e.g. Robaszynski \& Caron, 1995; Premoli Silva \& Sliter, 1999). Planktic foraminiferal assemblages recovered from Upper CretaceousLower Paleogene strata (Turonian? to early Danian in age) of Deep Sea Drilling Program (DSDP) Site 356, São Paulo Plateau (Figure 1), are herein restudied in a biostratigraphic approach. This planktic foraminiferal fauna was previously described by Premoli Silva \& Boersma (1977), and is revised herein on the basis of up-to-date planktic foraminiferal taxonomic revisions [Mesozoic Planktonic Foraminiferal Taxonomic Dictionary (http://portal.chronos.org/gridsphere/ gridsphere?cid=res foram)] and biostratigraphic schemes (e.g. Caron, 1985; Sliter, 1989; Premoli Silva \& Sliter, 1995; Robaszynski \& Caron, 1995; Huber et al., 2008; Petrizzo et al., 2011). Since studies on Cretaceous planktic foraminifera from the South Atlantic Ocean are patchy in the literature (e.g. Sliter, 1976; Premoli Silva \& Boersma, 1977; Caron, 1978; Krasheninnikov \& Basov, 1983; Viviers, 1987; Viviers \& Beurlen, 1987; Koutsoukos, 1989, 1992; Huber \& Leckie, 2011; Kochhann et al., 2013), detailed bio-/chronostratigraphic studies in the few sedimentary successions available are quite relevant.

\section{Geological setting}

The DSDP Site 356 is located at the eastern border of the São Paulo Plateau $\left(28^{\circ} 17.22^{\prime} \mathrm{S} / 41^{\circ} 05.28^{\prime} \mathrm{W}\right)$, at a water depth of 3,175 m (Figure 1), between the São Paulo High and the zone of salt structures (Mascle \& Renard, 1976). The plateau extends from $20^{\circ} \mathrm{S}$ (Vitória-Trindade chain) to $28^{\circ} \mathrm{S}$ (southern boundary of the Santos Basin, Brazilian continental margin), its basement is composed of continental crust (Macedo, 1990), and Albian to Recent strata were recovered at DSDP Site 356 (Supko et al., 1977). Three lithologic units (Supko et al., 1977) occur in the late Turonian? to early Danian studied stratigraphic interval (units 6, 5 and 4 from bottom to top; Figure 2). Unit 6 was characterized as dark-gray mudstones and clay-pebble conglomerates; unit 5 was defined as marly chalks; and unit 4 was described as nannofossil-foraminifera chalks.

\section{MATERIAL AND METHODS}

The studied Turonian? to lower Danian section of DSDP Site 356 comprises the interval from core 44 to core 29 [739.72 mbsf (meters below the seafloor) to $410.70 \mathrm{mbsf}]$. The studied hole was spot cored, with uncored intervals ranging from 38 to $9.5 \mathrm{~m}$ in thickness (Figure 2; Supko et al., 1977). Sixty samples were collected for the micropaleontological survey, consisting of one sample per section, with an average spacing of $1.5 \mathrm{~m}$ within cored intervals. The studied samples were sedimentologically characterized mainly as mudstones,
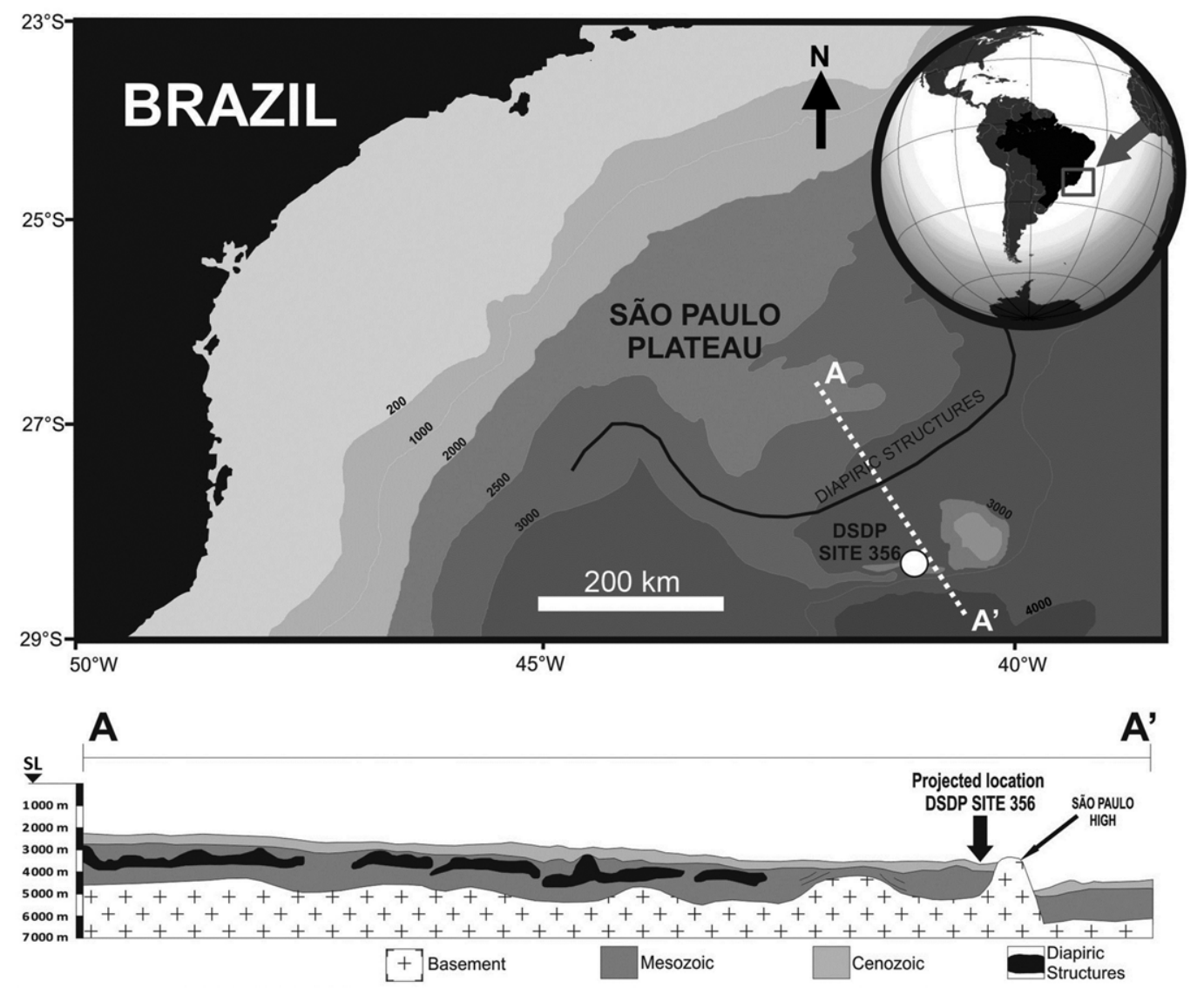

Figure 1. Top, bathymetric map of the studied area with the location of DSDP Site 356 (modified from Supko et al., 1977). Base, section A-A' with the location of the studied site (modified from Mascle \& Renard, 1976). Abbreviation: SL, sea level. 


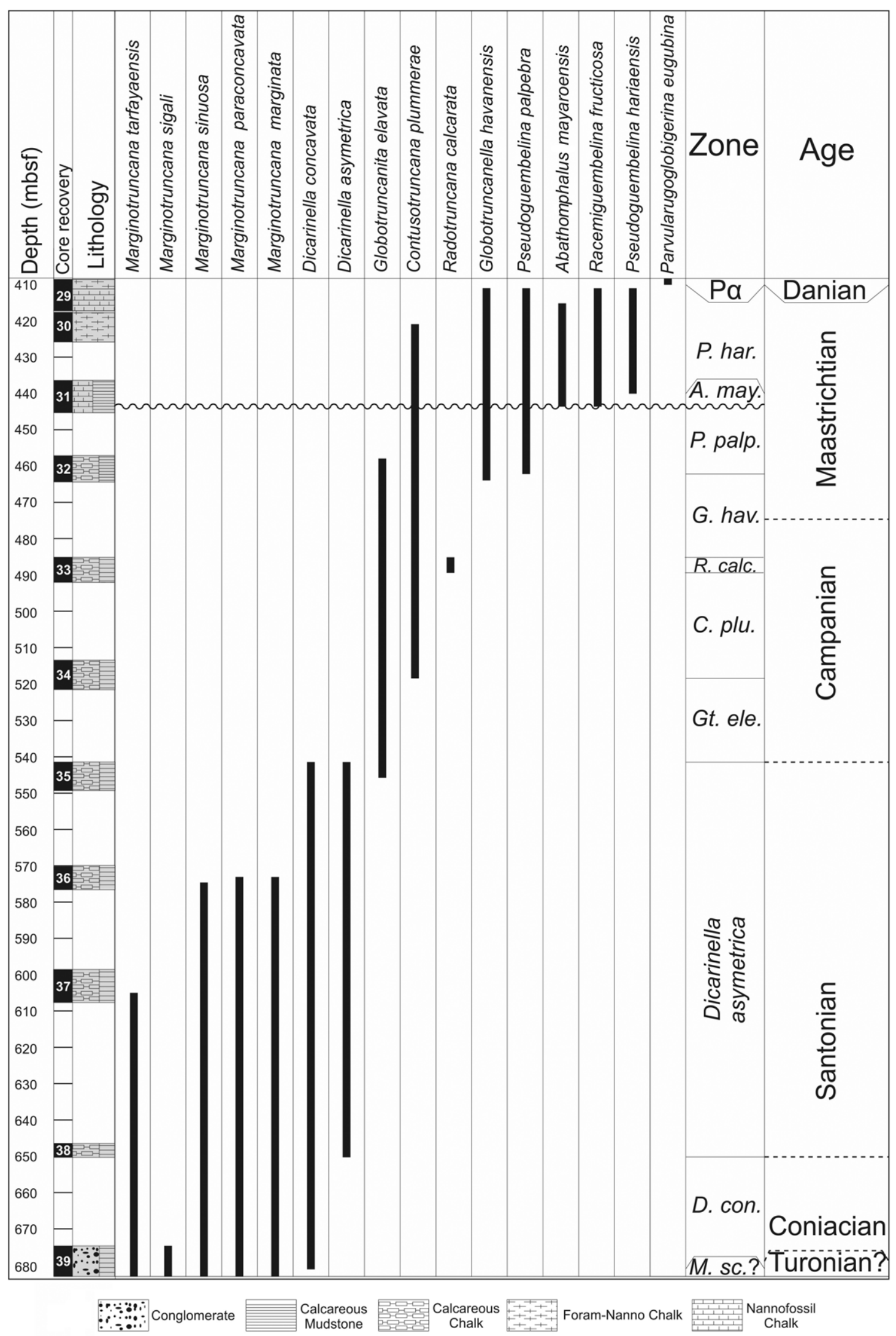

Figure 2. Stratigraphic range of selected planktic foraminiferal species in DSDP Site 356. Cored intervals are presented in black. Unconformity is represented by a wavy line. Abbreviations. A. may., Abathomphalus mayaroensis; $\boldsymbol{P}$. palp., Pseudoguembelina palpebra; G. hav., Globotruncanella havanensis; R. calc., Radotruncana calcarata; C. plu., Contusotruncana plummerae; Gt. ele., Globotruncanita elevata; D. con., Dicarinella concavata; M. sc., Marginotruncana schneegansi. 
calcareous mudstones, and chalks. Each sample was processed as follows: approximately $20 \mathrm{~g}$ of dried rock were crushed and soaked into $200 \mathrm{ml}$ of hydrogen peroxide solution (29\% $\mathrm{H}_{2} \mathrm{O}_{2}$ ) for 24 hours. Finally, residues were poured through a $38-\mu \mathrm{m}$ mesh sieve and around 300 foraminiferal specimens hand-picked and identified from each sample under a stereomicroscope. Selected specimens were imaged under scanning electron microscope (SEM) to assure accurate identifications. First occurrences (FOs) and last occurrences (LOs) of marker species were used in the identification of foraminiferal biozones boundaries in accordance with the studies of Caron (1985), Sliter (1989), Premoli Silva \& Sliter (1995) and Robaszynski \& Caron (1995), as well as the latest revisions of Huber et al. (2008) and Petrizzo et al. (2011). Preservation rating followed Petrizzo (2000), where: $\mathbf{G}=\operatorname{good}$ (planktic foraminifera show little diagenetic alteration and minor test fragmentation); $\mathbf{M}=$ moderate (specimens show minor to moderate test fragmentation and are moderately overgrown by secondary calcite); $\mathbf{P}=$ poor (most specimens are fragmented and it is difficult to identify them at the species level). Specimens figured herein are housed in the collections of the Museu de História Geológica do Rio Grande do Sul, Universidade do Vale do Rio dos Sinos (UNISINOS), Brazil [curatorial numbers (ULVG) are given after each specimens in Figure 3].

\section{RESULTS}

The taxonomic study of the recovered planktic foraminiferal assemblages enabled the identification of 59 species within the studied interval (Figure 4; Appendix 1). The finding of fewer species herein than in Premoli Silva \& Boersma (1977) is probably related to the better current understanding of the morphological plasticity of planktic foraminiferal taxa [several taxa reported by Premoli Silva \& Boersma (1977) are currently considered junior synonyms of species identified herein]. It is remarkable that both species richness and preservation improve upwards in the studied section; therefore, Turonian? to Santonian assemblages are composed of few species and generally show poor to moderate preservation, while Campanian and Maastrichtian ones are richer and moderately- to well-preserved (Figure 4). The sole studied Danian sample (which is the uppermost sample in the studied section) also yielded well-preserved planktic foraminiferal specimens and displayed low richness (Figure 4). Biostratigraphic data (Figures 2, 4) are described and discussed below, while marker species are shown in Figure 3.

The biostratigraphic scheme applied to the studied section is a compilation of previously published ones (Figure 5), mainly the propositions of Caron (1985), Sliter (1989), Premoli Silva \& Sliter (1995) and Robaszynski \& Caron (1995). The concepts of the zones Pseudoguembelina palpebra, Racemiguembelina fructicosa and Pseudoguembelina hariaensis are after Huber et al. (2008), while the definition of the Contusotruncana plummerae Interval Zone is after Petrizzo et al. (2011).

\section{Late Cretaceous-Early Paleogene biozonation}

The Marginotruncana schneegansi Partial-range Zone (Robaszynski \& Caron, 1995), Turonian in age, was tentatively identified from 682.77 to $681.27 \mathrm{mbsf}$. This zone is defined as the interval of occurrence of Marginotruncana schneegansi, from the LO of Helvetoglobotruncana helvetica to the FO of Dicarinella concavata (cf. Caron, 1985). Since the species that defines the basal boundary of this zone and the nominate taxon were not identified in the present study, the zone was tentatively assigned to the interval from the FOs of several late Turonian-Coniacian species (mainly marginotruncanids; see Figure 4) to the FO of Dicarinella concavata at Site 356.

The Dicarinella concavata Interval Zone (Sigal, 1955), late Turonian to Coniacian in age, was identified from the FO of the nominate taxon (681.27 mbsf) to the FO of Dicarinella asymetrica (648.27 mbsf). Besides the nominate taxon, typical species are Marginotruncana sinuosa, Muricohedbergella flandrini, Muricohedbergella simplex and Heterohelix globulosa.

The Dicarinella asymetrica Total-range Zone (Postuma, 1971; Santonian in age) was identified upward in the section, from the FO of the nominate taxon $(648.27 \mathrm{mbsf})$ to its LO (542.27 mbsf). It is worth mentioning that all marginotruncanids become extinct within this zone.

The Globotruncanita elevata Partial-range Zone (Dalbiez, 1955), early Campanian in age, was identified spanning the interval from 542.27 to $518.27 \mathrm{mbsf}$. This zone is defined as the partial-range of the nominate taxon, from the LO of Dicarinella asymetrica to the $\mathrm{FO}$ of Contusotruncana plummerae (cf. Petrizzo et al., 2011). Typical species of this zone are Contusotruncana fornicata and Archaeoglobigerina blowi.

On the basis of the proposition of Petrizzo et al. (2011), the Contusotruncana plummerae Interval Zone (Petrizzo et al., 2011), middle to late Campanian in age, was identified from the FO of the nominate taxon $(518.27 \mathrm{mbsf})$ to the FO of Radotruncana calcarata (489.77 mbsf). Typical species of this zone are Contusotruncana fornicata, Globotruncana sp. aff. G. bulloides, "Globigerinelloides" sp. aff. "G." prairiehillensis, and Archaeoglobigerina blowi. In its original proposition, this zone replaces the classic Globotruncana ventricosa interval zone (Petrizzo et al., 2011).

The Radotruncana calcarata Total-range Zone (Herm, 1962), late Campanian in age, was identified upwards in the section by the total-range of the nominate taxon (from 489.77 to $485.27 \mathrm{mbsf}$ ). Typical species of this interval are Contusotruncana fornicata, Globotruncana sp. aff. G. bulloides, "Globigerinelloides" sp. aff. "G." prairiehillensis, and Archaeoglobigerina blowi.

The Globotruncanella havanensis Partial-range Zone (Douglas, 1969), late Campanian-early Maastrichtian in age, was identified from 485.27 to 462.83 mbsf. This zone is defined as the partial interval of occurrence of the nominate taxon, from the LO of Radotruncana calcarata to the FO of Pseudoguembelina palpebra (cf. Huber et al., 2008). Typical species are Contusotruncana fornicata and Archaeoglobigerina blowi. 


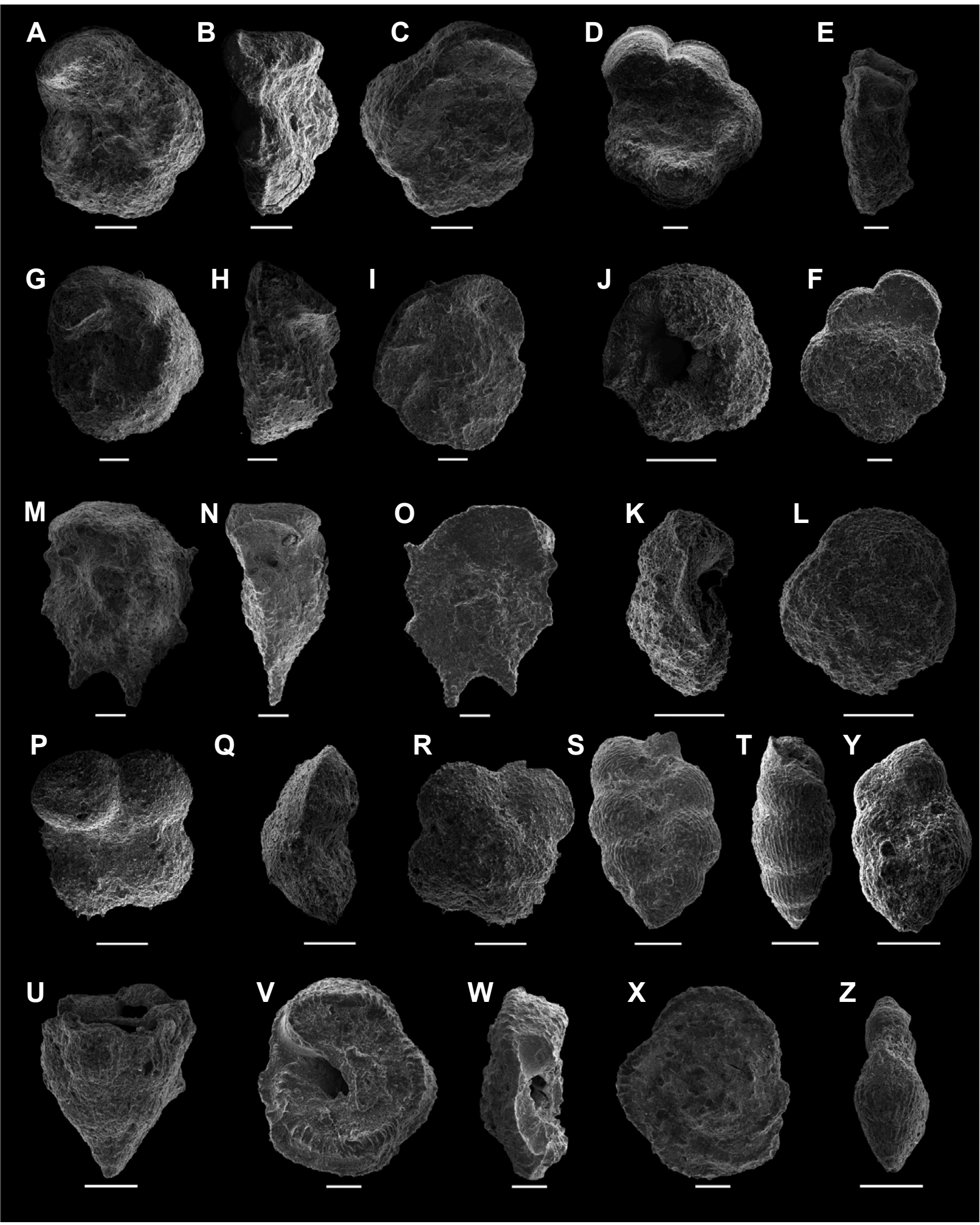

Figure 3. Scanning electron micrographs of selected planktic foraminiferal species from DSDP Site 356. A-C, Dicarinella concavata, 356-351, 77-80 cm (ULVG-10865); D-F, Dicarinella asymetrica, 356-38-3, 77-80 cm (ULVG-10866); G-I, Globotruncanita elevata, 356-33-5, 74-78 cm (ULVG-10867); J-L, Contusotruncana plummerae, 356-31-5, 51-56 cm (ULVG-10868); M-O, Radotruncana calcarata, 356-33-1, 77-80 cm (ULVG-10869); P-R, Globotruncanella havanensis, 356-32-6, 82-86 cm (ULVG-10870); S-T, Pseudoguembelina palpebra, 356-32-5, 83-87 cm (ULVG-10872); U, Racemiguembelina fructicosa, 356-29-5, 75-75 cm (ULVG-10873); V-X, Abathomphalus mayaroensis, 356-31-2, 77-80 cm (ULVG-10874); Y-Z, Pseudoguembelina hariaensis, 356-31-3, 76-79 cm (ULVG-10888). Scale bars $=100 \mu \mathrm{m}$. 


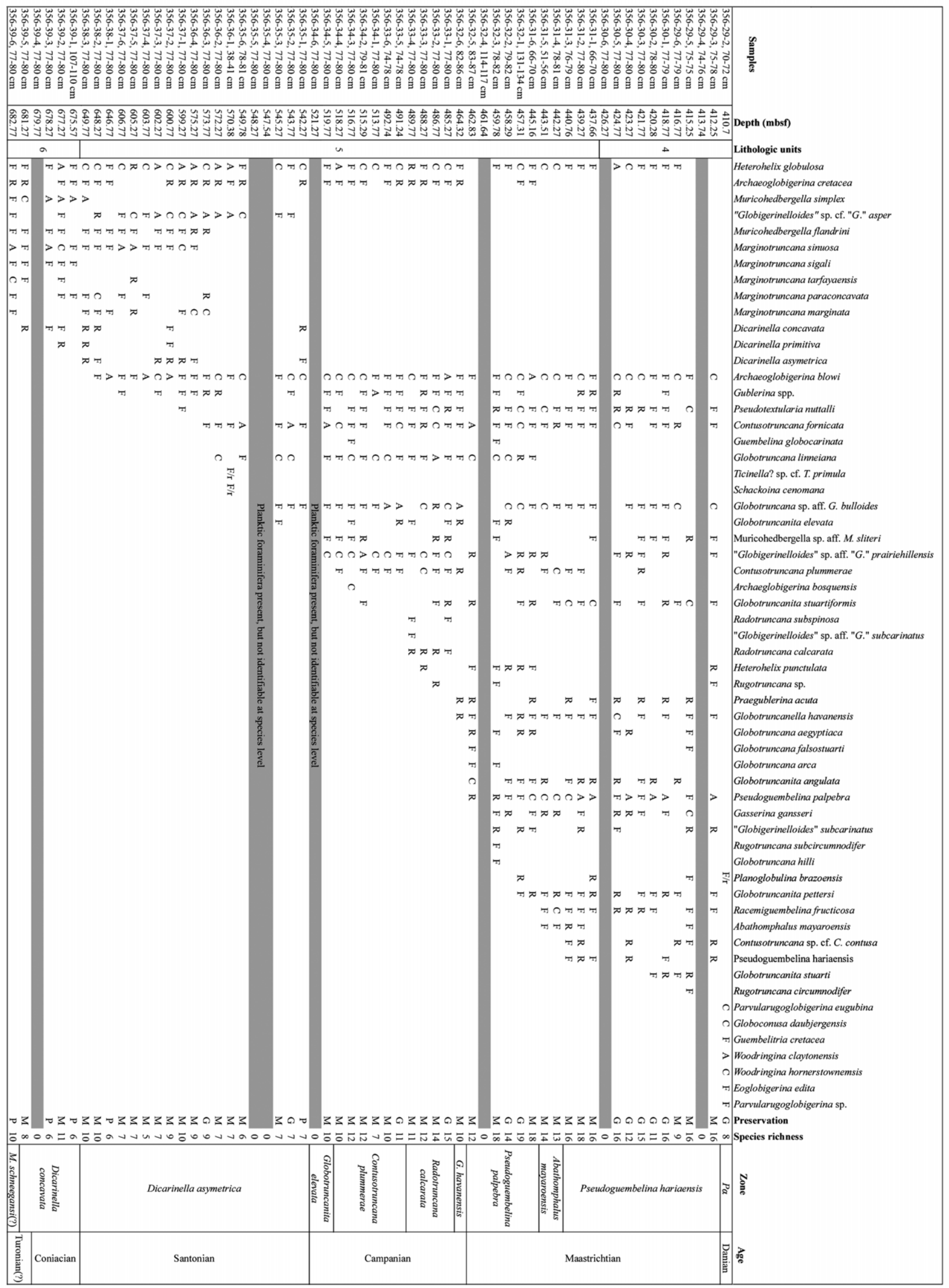

Figure 4. Relative abundances for planktic foraminiferal species from Turonian(?) to Danian strata of DSDP Site 356. Grey-shaded intervals represent barren samples. Abbreviations. Abundances are represented as follows: A, abundant (>25\%); C, common (10-25\%); F, few $(1-10 \%)$; $\mathbf{R}$, rare $(<1 \%)$. Preservation index is in accordance to Petrizzo's (2000) proposition, where: G, good; $\mathbf{M}$, moderate; $\mathbf{P}$, poor. The notation Ir refers to occurrences that are considered reworked. 


\begin{tabular}{|c|c|c|c|c|c|c|}
\hline \multirow{2}{*}{ 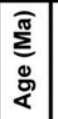 } & \multirow{2}{*}{ ฐ্ } & \multirow{2}{*}{ Caron (1985) } & \multirow{2}{*}{ Sliter (1989) } & \multirow{2}{*}{$\begin{array}{l}\text { Premoli Silva } \\
\text { \& Sliter (1995) }\end{array}$} & \multicolumn{2}{|c|}{ Robaszynski \& Caron (1995) } \\
\hline & & & & & Globotruncanids & Heterohelicids \\
\hline \multirow[t]{4}{*}{66} & \multirow{4}{*}{ 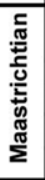 } & Abathomphalus mayaroensis & Abathomphalus mayaroensis & \multirow{2}{*}{ Abathomphalus mayaroensis } & \multirow{2}{*}{ Abathomphalus mayaroensis } & Pseudoguembelina hariaens \\
\hline & & Gansserina gansseri & Gansserina gansseri & & & \multirow{2}{*}{ Racemiguembelina fructicosa } \\
\hline & & Globotruncana aegyptiaca & Globotruncana aegyptiaca & Racemiguembelina fructicosa & \multirow[b]{2}{*}{ Gansserina gansseri } & \\
\hline & & Globotruncanella havanensis & Globotruncanella havanensis & Gansserina gansseri & & Planoglobulina acervulinoides \\
\hline & \multirow{5}{*}{ 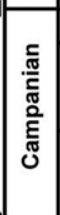 } & \multirow{3}{*}{ Globotruncana ventricosa } & \multirow{3}{*}{ Globotruncana ventricosa } & Globotruncana aegyptiaca & Globotruncana aegyptiaca & Pseudoguembelina excolata \\
\hline & & & & Globotruncanella havanensis & Globotruncanella havanensis & Pseudotextularia elegans \\
\hline & & & & \begin{tabular}{|l|} 
Globotruncanita calcarata \\
\end{tabular} & Globotruncanita calcarata & \multirow{2}{*}{ Pseudoguembelina costulata } \\
\hline & & \multirow[b]{2}{*}{ Globotruncanita elevata } & \multirow[b]{2}{*}{ Globotruncanita elevata } & Globotruncana ventricosa & Globotruncana ventricosa & \\
\hline \multirow{3}{*}{83.6} & & & & Globotruncanita elevata & Globotruncanita elevata & \begin{tabular}{|c|} 
Pseudoguembellina costellifera \\
Ventrilabrella eggeri \\
\end{tabular} \\
\hline & \multirow[b]{2}{*}{ 宛 } & \multirow[b]{2}{*}{ Dicarinella asymetrica } & \multirow{2}{*}{ Dicarinella asymetrica } & \multirow{2}{*}{ Dicarinella asymetrica } & \multirow{2}{*}{ Dicarinella asymetrica } & Sigalia deflaensis \\
\hline & & & & & & $\begin{array}{l}\text { sigalla decoratissima } \\
\text { Sigalia carphatica }\end{array}$ \\
\hline \multirow{3}{*}{$\begin{array}{l}86.3 \\
89.8\end{array}$} & & Dicarinella concavata & \multirow{2}{*}{ Dicarinella concavata } & \multirow{2}{*}{ Dicarinella concavata } & \multirow{2}{*}{ Dicarinella concavata } & \multirow{2}{*}{ Heterohelix globulosa } \\
\hline & & Dicarinella primitiva & & & & \\
\hline & Tur. & Marginotruncana sigali & Marginotruncana sigali & Marginotruncana sigali & Marginotruncana schneegansi & Heterohelix moremani \\
\hline
\end{tabular}

\begin{tabular}{|c|c|c|c|c|c|}
\hline 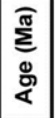 & $\begin{array}{l}\text { श्ञ } \\
\text { के }\end{array}$ & $\begin{array}{l}\text { Huber et al. } \\
\qquad(2008)\end{array}$ & $\begin{array}{l}\text { Petrizzo et al. } \\
\text { (2011) }\end{array}$ & This study & $\begin{array}{l}\text { Bioevents } \\
\text { (this study) }\end{array}$ \\
\hline \multirow[t]{3}{*}{66} & \multirow{4}{*}{ 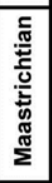 } & Pseudoguembelina hariaensis & & Pseudoguembelina hariaensis & P. hariaensis \\
\hline & & Abathomphalus mayaroensis & & Abathomphalus mayaroensis & A. mayaroensis \\
\hline & & Racemiguembelina fructicosa & & Racemiguembelina fructicosa & R. fructicosa \\
\hline \multirow[t]{5}{*}{72.1} & & Pseudoguembelina palpebra & & Pseudoguembelina palpebra & P. palpebra \\
\hline & \multirow{4}{*}{ 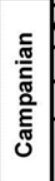 } & Globotruncanella havanensis & & Globotruncanella havanensis & \multirow{3}{*}{$\begin{array}{l}\text { R. calcarata } \\
\text { R. calcarata } \\
\text { C. plummerae }\end{array}$} \\
\hline & & Radotruncana calcarata & & Radotruncana calcarata & \\
\hline & & Globotruncana ventricosa & Contusotruncana plummerae & Contusotruncana plummerae & \\
\hline & & & & Globotruncanita elevata & \multirow{4}{*}{$\begin{array}{l}\text { D. asymetrica } \\
D \text { D. asymetrica } \\
\text { D. concavata }\end{array}$} \\
\hline \multirow[t]{3}{*}{83.6} & ஸ் & & & Dicarinella asymetrica & \\
\hline & Con. & & & Dicarinella concavata & \\
\hline & Tur. & & & Marginotruncana schneegansi & \\
\hline
\end{tabular}

Figure 5. Biostratigraphic framework for Late Cretaceous planktic foraminifera, presenting the studies discussed in the text and the composition applied to Site 356. Ages assigned to stages boundaries are given after Gradstein et al. (2012). Abbreviations: Tur., Turonian; Con., Coniacian; San., Santonian.

The Pseudoguembelina palpebra Interval Zone (Huber et al., 2008), early Maastrichtian in age, was identified from the FO of the nominate taxon $(462.83 \mathrm{mbsf})$ to the FOs of Racemiguembelina fructicosa and Abathomphalus mayaroensis, identified in the same sample (Figure 4). Typical species are Archaeoglobigerina blowi, Pseudoguembelina palpebra, and Contusotruncana fornicata.

Upward in the section, the Abathomphalus mayaroensis Interval Zone (Brönnimann, 1952), late Maastrichtian in age, was identified from the FO of the nominate taxon (443.51 mbsf) to the FO of Pseudoguembelina hariaensis (440.76 mbsf; cf. Huber et al., 2008). Typical species are Archaeoglobigerina blowi, Pseudotextularia nuttalli, Pseudoguembelina palpebra, and Racemiguembelina fructicosa. Since the FOs of Racemiguembelina fructicosa and Abathomphalus mayaroensis occur in the same sample, an unconformity can be suggested due to the absence of the Racemiguembelina fructicosa Interval Zone (Huber et al.,
2008) between the Pseudoguembelina palpebra Interval Zone and the Abathomphalus mayaroensis Interval Zone ( $c f$. Huber et al., 2008).

The Pseudoguembelina hariaensis Interval Zone (Robaszynski \& Caron, 1995), latest Maastrichtian in age, was identified from the FO of the nominate taxon (440.76 mbsf) to the level of extinction of virtually all Cretaceous taxa (412.25 mbsf; $c f$. Huber et al., 2008). Typical species are Archaeoglobigerina blowi, Pseudoguembelina palpebra, and Globotruncana sp. aff. G. bulloides.

Above $412.25 \mathrm{mbsf}$ (to the top of the studied interval), a Danian planktic foraminiferal assemblage assigned to the $\mathrm{P} \alpha$ Zone [Parvularugoglobigerina eugubina Total-range Zone (Luterbacher \& Premoli Silva, 1964); Olsson et al., 1999] was recovered. Since a single Danian sample was studied herein, it should not be assumed as representative of the entire P $\alpha$ Zone, but defines the top of the studied section. 


\section{Age/depth model}

An age/depth plot was generated by plotting depths (mbsf) at which several planktic foraminiferal bioevents were identified at DSDP Site 356 against their suggested ages [in accordance with Gradstein et al. (2012)] (Table 1; Figure 6). A continuous line in Figure 6 joins the bioevents that define the foraminiferal zones identified herein. Sedimentation rates (m/Ma; meters per million years) within the Cretaceous planktic foraminiferal zones were estimated as follows (Figure 6): $7.1 \mathrm{~m} / \mathrm{Ma}$ within the Dicarinella concavata Interval Zone; $35.6 \mathrm{~m} / \mathrm{Ma}$ within the Dicarinella asymetrica Total-range Zone; $5.4 \mathrm{~m} / \mathrm{Ma}$ within the Globotruncanita elevata Partialrange Zone; $9.4 \mathrm{~m} / \mathrm{Ma}$ within the Contusotruncana plummerae Interval Zone; $9.6 \mathrm{~m} / \mathrm{Ma}$ within the Radotruncana calcarata Total-range Zone; $5.6 \mathrm{~m} / \mathrm{Ma}$ within the Globotruncanella havanensis Partial-range Zone; $7.5 \mathrm{~m} / \mathrm{Ma}$ within the Pseudoguembelina palpebra Interval Zone; $1.5 \mathrm{~m} / \mathrm{Ma}$ within the Abathomphalus mayaroensis Interval Zone; and $22.5 \mathrm{~m} /$ Ma within the Pseudoguembelina hariaensis Interval Zone. In addition, a time span of at least $0.96 \mathrm{Ma}$ is suggested for the unconformity between the Pseudoguembelina palpebra Interval Zone and the Abathomphalus mayaroensis Interval Zone (Figure 6), as discussed below.

\section{DISCUSSION}

From 682.77 mbsf (core 39) to 410.7 mbsf (core 29), age assignments made herein and those reported by Premoli Silva \& Boersma (1977) show quite good agreement. The interval attributed herein to the Marginotruncana schneegansi, Dicarinella concavata, and Dicarinella asymetrica zones (Figures 2,4) was assigned to the Globotruncana concavata

Table 1. Age (according to Gradstein et al., 2012) and depth (at DSDP Site 356) of the bioevents used in the age/depth plot.

\begin{tabular}{lcc}
\hline \multicolumn{1}{c}{ Bioevent } & Age (Ma) & Depth (mbsf) \\
\hline LO Racemiguembelina fructicosa & 66.04 & 412.25 \\
LO Abathomphalus mayaroensis & 66.35 & 415.25 \\
LO Gasserina gansseri & 66.49 & 415.25 \\
FO Pseudoguembelina hariaensis & 67.3 & 440.67 \\
LO Globotruncana linneiana & 68.37 & 445.16 \\
FO Abathomphalus mayaroensis & 69.18 & 443.51 \\
FO Racemiguembelina fructicosa & 70.14 & 443.51 \\
FO Pseudoguembelina palpebra & 71.75 & 462.83 \\
FO Gasserina gansseri & 72.97 & 459.78 \\
FO Globotruncana aegyptiaca & 74.00 & 462.83 \\
LO Radotruncana calcarata & 75.71 & 485.27 \\
FO Globotruncanella havanensis & 75.94 & 464.32 \\
FO Radotruncana calcarata & 76.18 & 489.77 \\
FO Contusotruncana plummerae & 79.20 & 518.27 \\
FO Globotruncanita elevata & 83.64 & 545.27 \\
LO Dicarinella asymetrica & 83.64 & 542.27 \\
LO Dicarinella concavata & 83.64 & 542.27 \\
FO Dicarinella asymetrica & 86.66 & 649.77 \\
FO Dicarinella concavata & 91.08 & 681.27 \\
\hline
\end{tabular}

concavata (= Dicarinella concavata herein) and Globotruncana concavata carinata (= Dicarinella asymentrica herein) zones by Premoli Silva \& Boersma (1977), differing only in a possible Turonian age for one sample (356-39-6, 77-80 $\mathrm{cm})$, attributed herein to the Marginotruncana schneegansi Partial-range Zone. Improved biostratigraphic resolution in the present study, mainly in the Campanian-Maastrictian interval, is likely a result of the application of the latest biostratigraphic revisions (e.g. Huber et al., 2008; Petrizzo et al., 2011). The Campanian interval of DSDP Site 356 was herein attributed to the Globotruncanita elevata, Contusotruncana plummerae, Radotruncana calcarata, and Globotruncanella havanensis zones (Figures 2, 4), while Premoli Silva \& Boersma (1977) identified the Globotruncana elevata (= Globotruncanita elevata herein), Globotruncana calcarata (= Radotruncana calcarata herein) and Globotruncana tricarinata zones in the same stratigraphic interval. Maastrichtian strata were herein attributed to the Pseudoguembelina palpebra, Abathomphalus mayaroensis, and Pseudoguembelina hariaensis zones (Figures 2, 4), whereas Premoli Silva \& Boersma (1977) identified the Globotruncana gansseri and Abathomphalus mayaroensis zones for the same interval.

In the same way as reported by Huber et al. (2008), rare and sporadic occurrences of the zonal markers Goblotruncana aegyptiaca and Gansserina gansseri hampered the accurate identification of the nominate planktic foraminiferal zones for those species. Therefore, the biozonation proposed by Huber et al. (2008) was applied herein to the upper CampanianMaastrichtian interval of DSDP Site 356. It is also worth mentioning that the FOs of Globotruncana aegyptiaca, Gansserina gansseri, and Globotruncanella havanensis fall quite distant from the line that joins the bioevents used in the planktic foraminiferal zonation presented in the age/depth plot (Figure 6). This pattern may be explained by their sporadic and rare occurrences, leading to the inaccurate identification of these bioevents (e.g. Huber et al., 2008), and/or by the presence of an uncored interval of about $20 \mathrm{~m}$ below core 32, within which these species could have their real FOs (Figure 2). On the other hand, the FO of Globotruncanita elevata and the LOs of Gansserina gansseri and Abathomphalus mayaroensis showed good alignment with the continuous line in the age/depth plot (Figure 6). The reliability in identifying the Contusotruncana plummerae Interval Zone in Campanian strata of the South Atlantic Ocean, likewise, was confirmed herein, as previously suggested by Petrizzo et al. (2011), on the basis of sedimentary successions from the Tethyan region, Pacific and Indian oceans.

Robaszynski \& Caron (1995) noticed that Racemiguembelina fructicosa and Contusotruncana contusa are supposed to have their FOs below the FO of Abathomphalus mayaroensis, defining the Racemiguembelina fructicosa Interval Zone, from the FO of the nominate taxon to the FO of Abathomphalus mayaroensis (Huber et al., 2008). Since Racemiguembelina fructicosa and Abathomphalus mayaroensis have their FOs in the same sample in the studied site, and since Contusotruncana sp. cf. C. contusa first appears within the Abathomphalus mayaroensis interval zone (Figure 4), an unconformity can 


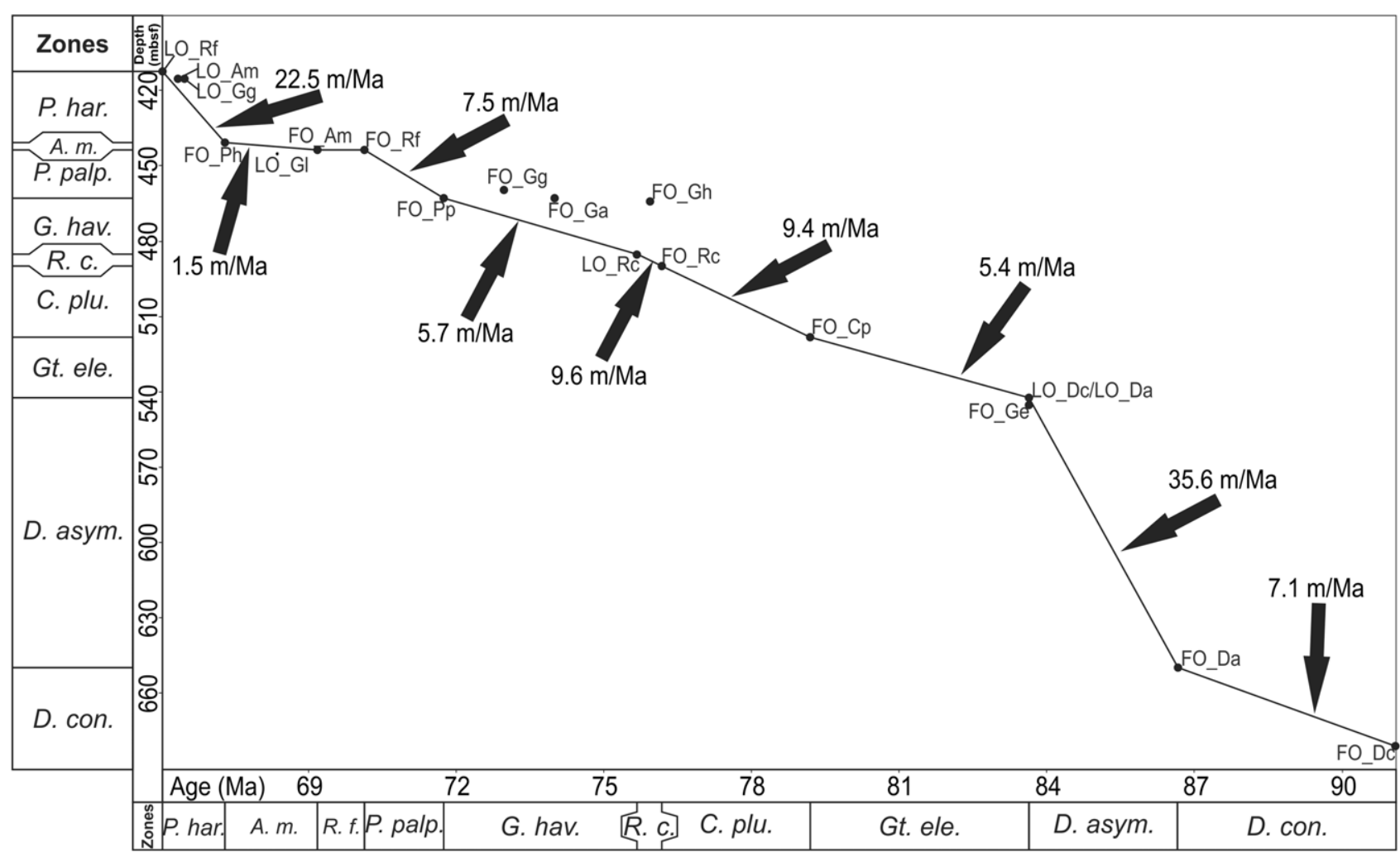

Figure 6. Age/depth plot for DSDP Site 356. Age (according to Gradstein et al., 2012) and depth (at Site 356) of the bioevents (FOs and LOs) are given in Table 1. Inferences of sedimentation rates for each planktic foraminiferal zone identified herein are also given. Abbreviations. Species names: Ph, Pseudoguembelina hariaensis; Am, Abathomphalus mayaroensis; Rf, Racemiguembelina fructicosa; Pp, Pseudoguembelina palpebra; GI, Globotruncana linneiana; Gg, Gansserina gansseri; Ga, Globotruncana aegyptiaca; Gh, Globotruncanella havanensis; Rc, Radotruncana calcarata; Cp, Contusotruncana plummerae; Ge, Globotruncanita elevata; Dc, Dicarinella concavata; Da, Dicarinella asymetrica. Zones follow those of Figure 2, except for: P. har., Pseudoguembelina hariaensis; $\boldsymbol{A}$. m., Abathomphalus mayaroensis; R. f., Racemiguembelina fructicosa; $\boldsymbol{R}$. c., Radotruncana calcarata; $\boldsymbol{D}$. asym., Dicarinella asymetrica.

be suggested within core 31 (Figure 2) due to the direct superposition of the Pseudoguembelina palpebra Interval Zone by the Abathomphalus mayaroensis Interval Zone. An abrupt change of color observed in core photographs between 445.51 and $443.51 \mathrm{mbsf}$ (Supko et al., 1977), from dark marly chalk to light colored chalk, could well represent this unconformity, spanning at least $0.96 \mathrm{Ma}$ (Figure 6).

Sedimentation rates showed high variability within the studied section (Figure 6). High sedimentation rates were observed in the Santonian (Dicarinella asymentrica Total-range Zone) and in the uppermost Maastrichtian (Pseudoguembelina hariaensis Interval Zone) intervals of Site 356 , while lower and more constant values were observed in the Campanian-lower Maastrichtian interval (Globotruncanita elevata Partial-range Zone to Pseudoguembelina palpebra Interval Zone). The identification of high sedimentation rates within the Dicarinella asymentrica Total-range Zone is in accordance with previous studies that have suggested the same pattern for Santonian strata in some Brazilian continental margin basins, including the closely related Santos Basin (Moreira et al., 2007). This pattern may be a consequence of the increased clastic input and shelf progradation driven by the uplift of the Serra do Mar and Serra da Mantiqueira mountain ranges, which peaked at this time interval (Almeida
\& Carneiro, 1998; Cobbold et al., 2001; Modica \& Brush, 2004; Contreras et al., 2010). The lowest sedimentation rate identified in the studied section was within the Abathomphalus mayaroensis Interval Zone. It may represent a real trend as well as be a result of the absence of part of this zone due to the unconformity between the Pseudoguembelina palpebra and Abathomphalus mayaroensis zones (Figures 2,6). The sampling resolution applied herein, however, did not enable to support any of these hypotheses.

It is worth mentioning that Plummerita hantkeninoides, a taxon of reported biostratigraphic usefulness ( $c f$. Koutsoukos, 2006) that evolved within the last $0.3 \mathrm{Ma}$ of the Maastrichtian, is absent from the studied section (Figure 4). Despite the fact that open-ocean pelagic carbonate sediments of this age were probably recovered at DSDP Site 356 , the absence of this species from the studied site could be interpreted as a consequence of its probable preference for inhabiting eutrophic shelf to upper slope environments (Abramovich \& Keller, 2002; MacLeod et al., 2007; Huber et al., 2008), or due to its low potential of preservation. In addition, this species could have presented a paleobiogeographic distribution restricted to low-latitude areas (e.g. Koutsoukos, 2006; Gallala, 2013), being absent from higher-latitude sites. Therefore, it is more convenient to apply the concept 
of the Pseudoguembelina hariaensis Interval Zone to upper Maastrichtian strata of DSDP Site 356, since the nominate species had a wider paleobiogeographic distribution (e.g. Huber et al., 2008).

\section{CONCLUDING REMARKS}

Fifty-nine planktic foraminiferal species were identified within the studied interval of DSDP Site 356. The following planktic foraminiferal zones (Turonian? to early Danian in age) were identified: Marginotruncana schneegansi, Dicarinella concavata, Dicarinella asymetrica, Globotruncanita elevata, Contusotruncana plummerae, Radotruncana calcarata, Globotruncanella havanensis, Pseudoguembelina palpebra, Abathomphalus mayaroensis, Pseudoguembelina hariaensis, and $\mathrm{P} \alpha$.

The reliability in identifying the Contusotruncana plummerae Interval Zone (Campanian in age) in Cretaceous sections of the South Atlantic Ocean is confirmed herein. The direct superposition of the Pseudoguembelina palpebra Interval Zone by the Abathomphalus mayaroensis Interval Zone (both Maastrichtian in age) suggests an unconformity spanning at least $0.96 \mathrm{Ma}$ within core 31 of DSDP Site 356. High sedimentation rates were inferred for the Santonian (Dicarinella asymentrica Total-range Zone) and in the uppermost Maastrichtian (Pseudoguembelina hariaensis Interval Zone) intervals of the studied site. Lower and more constant values in sedimentation rates, however, are suggested for the Campanianlower Maastrichtian interval (Globotruncanita elevata Partialrange Zone to Pseudoguembelina palpebra Interval Zone).

\section{ACKNOWLEDGEMENTS}

The authors are grateful to the Integrated Ocean Drilling Program (IODP) for providing the studied samples. The micropaleontologists E.A.M. Koutsoukos (Universität Heidelberg) and M.C. Viviers (CENPES/PETROBRAS) are acknowledged for providing helpful discussions and revising the early drafts of the manuscript, and M.G. da Silva (ITT Fossil/UNISINOS) for taking the SEM photographs. The foraminiferologist B.T. Huber (Smithsonian Institution) is thanked for taxonomic discussion regarding selected specimens. Constructive criticism by N. Malumián (Servicio Geológico Minero Argentino) and one anonymous reviewer are highly appreciated and led to improvements of the first version of the manuscript.

\section{REFERENCES}

Abramovich, S. \& Keller, G. 2002. High stress late Maastrichtian environment: inference from planktonic foraminifera from Tunisia. Palaeogeography, Palaeoclimatology, Palaeoecology, 178:145-164. doi: 10.1016/S0031-0182(01)00394-7

Almeida, F.F.M. \& Carneiro, C.D.R. 1998. Origem e evolução da Serra do Mar. Revista Brasileira de Geociências, 28:135-150.

Brönnimann, P. 1952. Globigerinidae from the upper Cretaceous (Cenomanian-Maestrichtian) of Trinidad, B.W.I. Bulletins of American Paleontology, 34:5-71.
Caron, M. 1978. Cretaceous planktonic foraminifera from DSDP Leg 40, southeastern Atlantic Ocean. In: H.M. Bolli et al. (eds.) Initial Reports of the Deep Sea Drilling Project, Washington, United States Government Printing Office, p. 651-678 (Volume 40). doi:10.2973/dsdp.proc. 40.114 .1978

Caron, M. 1985. Cretaceous planktonic foraminifera. In: H.M. Bolli; J.B. Saunders \& K. Perch-Neilsen (eds.) Plankton Stratigraphy, Cambridge University Press, p. 17-86.

Cobbold, P.R.; Szatmari, P.; Demercian, L.S.; Coelho, D. \& Rosello, E.A. 2001. Seismic and experimental evidence for the thinskinned horizontal shortening by convergent radial gliding on evaporates, deep-water Santos Basin, Brazil. In : M.P.A. Jackson; D.G. Roberts \& S. Snelson (eds.) Salt Tectonics: a Global Perspective, Tulsa, AAPG, p. 305-321 (Memoir 65).

Contreras, J.; Zühlke, R.; Bowman, S. \& Bechstädt, T. 2010 Seismic stratigraphy and subsidence analysis of the southern Brazilian margin (Campos, Santos and Pelotas basins). Marine and Petroleum Geology, 27:1952-1980. doi: 10.1016/j. marpetgeo.2010.06.007

Dalbiez, F. 1955. The genus Globotruncana in Tunisia. Micropaleontology, 1:161-171.

Gallala, N. 2013. Planktonic foraminiferal biostratigraphy and correlation across the Cretaceous-Paleogene transition at the Tethyan and the Atlantic realms. Paleontology Journal, 2013:120. doi: $10.1155 / 2013 / 643278$

Gradstein, F.M.; Ogg, J.G.; Schmitz, M.D. \& Ogg, G.M. 2012. The Geologic Time Scale 2012. Amsterdam, Elsevier, 1162 p.

Douglas, R.G. 1969. Upper Cretaceous planktonic foraminifera in northern California. Part 1 - Systematics. Micropaleontology, 15:151-209.

Herm, D. 1962. Stratigraphische und mikropaläontologische Untersuchungen der Oberkreide im Lattengebirge und im Nierental. Bayerische Akademie der Wissenschaften, Abhandlungen, 104:1-119.

Huber, B.T. \& Leckie, R.M. 2011. Planktic foraminiferal species turnover across deep-sea Aptian/Albian boundary sections. Journal of Foraminiferal Research, 41:53-95. doi: 10.2113/ gsjfr.41.1.53

Huber, B.T.; MacLeod, K.G. \& Tur. N.A. 2008. Chronostratigraphic framework for Upper Campanian-Maastrichtian sediments on the Blake Nose Plateau (subtropical North Atlantic). Journal of Foraminiferal Research, 38:162-182. doi: 10.2113/gsjfr.38.2.162

Kochhann, K.G.D.; Koutsoukos, E.A.M.; Fauth, G. \& Sial, A.N. 2013. Aptian-Albian planktic foraminifera from DSDP Site 364 (offshore Angola): biostratigraphy, paleoecology, and paleoceanographic significance. Journal of Foraminiferal Research, 43:443-463. doi: 10.2113/gsjfr.43.4.443

Koutsoukos, E.A.M. 1989. Mid- to Late Cretaceous Microbiostratigraphy, Palaeoecology and Palaeogeography of the Sergipe Basin, Northeastern Brazil. Council for National Academic Awards, Polytechnic South West, Ph.D. thesis, 886 p.

Koutsoukos, E.A.M. 1992. Late Aptian to Maastrichtian foraminiferal biogeography and palaeoceanography of the Sergipe Basin, Brazil. Palaeogeography, Palaeoclimatology, Palaeoecology, 92:295-324. doi: 10.1016/0031-0182(92)90089-N

Koutsoukos, E.A.M. 2006. The Cretaceous-Paleogene boundary at the Poty section, NE Brazil: foraminiferal record and sequence of events - a review. Anuário do Instituto de Geociencias UFRJ, 29:95-107.

Krasheninnikov, V.A. \& Basov, I.A. 1983. Stratigraphy of Cretaceous sediments of the Falkland Plateau based on planktonic foraminifers, Deep Sea Drilling Project, Leg 71. In: W.J. 
Ludwig et al. (eds.) Initial Reports of the Deep Sea Drilling Project, Washington, United States Government Printing Office, p. 789-820 (Volume 71).

Lee, J.J. 1989. Phylum Granuloreticulosa (Foraminifera). In: L. Margulis et al. (eds.) Handbook of Protoctista, Jones and Bartlett Publishers, p. 524-548.

Loeblich, A.R. \& Tappan, H. 1987. Foraminiferal Genera and their Classification. New York, Van Nostrand Reinhold Co., 970 p.

Loeblich, A.R. \& Tappan, H. 1992. Present status of Foraminiferal Classification. In: Y. Takayanagi \& T. Saito (eds.) Studies in Benthic Foraminifera, Tokai University Press, p. 93-102.

Luterbacher, H.P. \& Premoli Silva, I. 1964. Biostratigrafia del limite Cretaceo-Terziario nell'Appenino centrale. Rivista Italiana di Paleontologia e Stratigrafia, 70:67-128.

Macedo, J.M. 1990. Evolução tectônica da Bacia de Santos e áreas continentais adjacentes. In: R. Gabaglia \& E.J. Milani (eds.) Origem e evolução das bacias sedimentares, PETROBAS, $\mathrm{p}$. 361-376.

MacLeod, K.G.; Whitney, D.; Huber, B.T. \& Koeberl, C. 2007. Impact and extinction in remarkably complete $\mathrm{K} / \mathrm{T}$ boundary sections from Demerara Rise, tropical western North Atlantic. Bulletin of the Geological Society of America, 119:101-115. doi:10.1130/B25955.1

Mascle J. \& Renard V. 1976. The marginal São Paulo Plateau, comparison with the Southern Angola Margin. Anais da Academia Brasileira de Ciências, 48:187-198.

Modica, C.J. \& Brush, E.R. 2004. Postrift sequence stratigraphy, paleogeography and fill history of the deep-water Santos Basin, offshore southeast Brazil. Tulsa, AAPG, p. 923-945 (Bulletin 88). doi: 10.1306/01220403043

Moreira, J.L.P.; Madeira, C.V.; Gil, J.A. \& Machado, M.A.P. 2007. Bacia de Santos. Boletim de Geociencias da Petrobras, 15:531-549.

Olsson, R.K.; Hemleben, C.; Berggren, W.A. \& Huber, B.T. 1999. Atlas of Paleocene Planktic Foraminifera. Washington, Smithsonian Contributions to Paleobiology, $252 \mathrm{p}$.

Petrizzo, M.R. 2000. Late Cretaceous planktonic foraminifera from Kerguelen Plateau (ODP Leg 183): new data to improve the Southern Ocean biozonation. Cretaceous Research, 22:829-855. doi: 10.1006/cres.2001.0290

Petrizzo, M.R.; Falzoni, F. \& Premoli Silva, I. 2011. Identification of the base of the lower-to-middle Campanian Globotruncana ventricosa Zone: comments on reliability and global correlations. Cretaceous Research, 32:387-405. doi: 10.1016/j. cretres.2011.01.010
Postuma, J. 1971. Manual of Planktonic Foraminifera. Amsterdam, Elsevier Publishing Co., 420 p.

Premoli Silva, I. \& Boersma, A. 1977. Cretaceous planktonic foraminifers - DSDP Leg 39 (South Atlantic). In: P.R. Supko et al. (eds.) Initial Reports of the Deep Sea Drilling Project, Washington, United States Government Printing Office, p. 615641 (Volume 39). doi:10.2973/dsdp.proc.39.128.1977

Premoli Silva, I. \& Sliter, W.V. 1995. Cretaceous planktonic foraminiferal biostratigraphy and evolutionary trends from the Bottaccioni Section, Gubbio, Italy. Palaeontographia Italica, 82:1-89.

Premoli Silva, I. \& Sliter, W.V. 1999. Cretaceous paleoceanography: evidence from planktonic foraminiferal evolution. In: E. Barrera \& C.C. Johnson (eds.) Evolution of the Cretaceous OceanClimate System, Geological Society of America, p. 301-328 (Special Paper 332).

Robaszynski, F. \& Caron, M. 1995. Foraminifères planctoniques du Crètacè: commentaire de la zonation Europe-Mèditerranèe. Bulletin de la Sociètè Gèologique de France, 6:681-692.

Sigal, J. 1955. Notes micropaléontalogiques nord-africaines. 1. Du Cénomanien au Santonien: zones et limites en faciès pélagiques. Compte Rendu Sammairedes Seancesde la Societe Géologique de France, 8:157-160.

Sliter, W.V. 1976. Cretaceous foraminifers from the southwestern Atlantic Ocean, Leg 36, Deep Sea Drilling Project. In: P.F. Barker et al. (eds.) Initial Reports of the Deep Sea Drilling Project, Washington, United States Government Printing Office, p. 519-573 (Volume 36).

Sliter, W.V. 1989. Biostratigraphic zonation for Cretaceous planktonic foraminifers examined in thin section. Journal of Foraminiferal Research, 19:1-19. doi: 10.2113/gsifr.19.1.1

Supko, P.R. et al. 1977. Initial Reports of the Deep Sea Drilling Project. Washington, U.S. Government Printing Office, 1132 p. (Volume 39). doi:10.2973/dsdp.proc.39.1977

Viviers, M. C. 1987. Foraminíferos planctônicos no Cretáceo médio da Bacia de Santos, Brasil. Revista Brasileira de Geociências, 17:154-161.

Viviers, M.C. \& Beurlen, G. 1987. Sobre alguns níveis de correlação bioestratigráfica regional (foraminíferos planctônicos) no Cretáceo brasileiro. Revista Brasileira de Geociências, 17:106110 .

Received in December, 2013; accepted in April, 2014. 
Appendix 1. List of the species identified in the present study. Suprageneric classification follows Loeblich \& Tappan (1987, 1992) modified by Lee (1989). Species concepts are mainly based on the Mesozoic Planktonic Foraminiferal Taxonomic Dictionary (http://portal.chronos.org/ gridsphere/gridsphere?cid=res_foram).

Supergroup RHIZARIA Cavalier-Smith, 2002

Class FORAMINIFERA d'Orbigny, 1826

Order GLOBIGERININA Delage \& Hérouard, 1896

Family GUEMBELITRIIDAE Longoria, 1974

Genus Guembelitria Cushman, 1933

Guembelitria cretacea Cushman, 1933

Genus Woodringina Loeblich \& Tappan, 1957

Woodringina claytonensis Loeblich \& Tappan, 1957

Woodringina hornerstownemsis Olsson, 1960

Family HETEROHELICIDAE Cushman, 1927

Genus Heterohelix Ehrenberg, 1843

Heterohelix punctulata (Cushman, 1938)

Heterohelix globulosa (Ehrenberg, 1840)

Genus Planoglobulina Cushman, 1927

Planoglobulina brazoensis Martin, 1972

Genus Pseudotextularia Rzehak, 1891

Pseudotextularia nuttalli (Voorvijk, 1937)

Genus Racemiguembelina Montanaro Gallitelli, 1957

Racemiguembelina fructicosa (Egger, 1899)

Genus Praegublerina Georgescu et al., 2009

Praegublerina acuta (de Klasz, 1953)

Genus Gublerina Kikoine, 1948

Gublerina spp

Genus Pseudoguembelina Brönnimann \& Brown, 1953

Pseudoguembelina hariaensis Nederbragt, 1990

Pseudoguembelina palpebra Brönnimann \& Brown, 1953

Genus Guembelina Egger, 1900

Guembelina globocarinata Cushman, 1938

Family GLOBIGERINELLOIDIDAE Longoria, 1974

Genus Globigerinelloides Cushman \& ten Dam, 1948

"Globigerinelloides" subcarinatus (Brönnimann, 1952)

1952)

"Globigerinelloides" sp. aff. "G." subcarinatus (Brönnimann,

1967

“Globigerinelloides" sp. aff. "G.” prairiehillensis Pessagno,

"Globigerinelloides" sp. cf. "G." asper (Ehrenberg, 1854)

Family SCHACKOINIDAE Pokorny, 1958

Genus Schackoina Thalmann, 1932

Schackoina cenomana (Schacko, 1897)

Family HEDBERGELLIDAE Loeblich \& Tappan, 1961

Genus Muricohedbergella Huber \& Leckie, 2011

Muricohedbergella flandrini (Porthault, 1970)

Muricohedbergella sp. aff. M. sliteri (Huber, 1990)

Muricohedbergella simplex (Morrow, 1934)

Family Rotaliporidae Sigal, 1958

Genus Ticinella Reichel, 1950

Ticinella? sp. cf. T. primula Lutherbacher, 1963

Family GLOBOTRUNCANIDAE Brotzen, 1942

Genus Contusotruncana Korchagin, 1982

Contusotruncana fornicata (Plummer, 1931)

Contusotruncana plummerae (Gandolfi, 1955)

Contusotruncana sp. cf. C. contusa (Cushman, 1926)
Genus Gasserina Caron et al., 1984

Gasserina gansseri (Bolli, 1951)

Genus Globotruncana Cushman, 1927

Globotruncana hilli Pessagno (1967)

Globotruncana aegyptiaca Nakkady, 1950

Globotruncana falsostuarti Sigal, 1952

Globotruncana arca (Cushman, 1926)

Globotruncana sp. aff. G. bulloides Vogler, 1941

Globotruncana linneiana (d'Orbigny, 1839)

Genus Globotruncanita Reiss, 1957

Globotruncanita stuarti (de Lapparent, 1918)

Globotruncanita stuartiormis (Dalbiez, 1955)

Globotruncanita pettersi (Gandolfi, 1955)

Globotruncanita angulata (Tilev, 1951)

Globotruncanita elevata (Brotzen, 1934)

Genus Marginotruncana Hofker, 1956

Marginotruncana sinuosa Porthault, 1970

Marginotruncana sigali (Reichel, 1950)

Marginotruncana tarfayaensis (Lehmann, 1963)

Marginotruncana paraconcavata Porthault, 1970

Marginotruncana marginata (Reuss, 1845)

Genus Radotruncana El-Naggar, 1971

Radotruncana calcarata (Cushman, 1927)

Radotruncana subspinosa (Pessagno, 1967)

Genus Globotruncanella Reiss, 1957

Globotruncanella havanensis (Voorwijk, 1937)

Genus Abathomphalus Bolli et al., 1957

Abathomphalus mayaroensis (Bolli, 1951)

Genus Dicarinella Porthault, 1970

Dicarinella concavata (Brotzen, 1934)

Dicarinella primitiva (Dalbiez, 1955)

Dicarinella asymetrica (Sigal, 1952)

Family RUGOGLOBIGERINIDAE Subbotina, 1959

Genus Archaeoglobigerina Pessagno, 1967

Archaeoglobigerina blowi Pessagno, 1967

Archaeglobigerina bosquensis Pessagno, 1967

Archaeoglobigerina cretacea (d'Orbigny, 1840)

Genus Rugotruncana Brönnimann, 1952

Rugotruncana sp.

Rugotruncana circumnodifer (Finlay, 1940)

Rugotruncana subcircumnodifer (Gandolfi, 1955)

Family EOGLOBIGERINIDAE Blow, 1979

Genus Eoglobigerina Morozova, 1959

Eoglobigerina edita (Subbotina, 1953)

Genus Globoconusa Khalilov, 1956

Globoconusa daubjergensis (Brönnimann, 1953)

Genus Parvularugoglobigerina Hofker, 1978

Parvularugoglobigerina eugubina (Luterbacher \& Premoli

Silva, 1964)

Parvularugoglobigerina sp. 